\title{
RECLAMAÇÃO CONSTITUCIONAL: UMA ALTERNATIVA POSSÍVEL PARA \\ A SUPERAÇÃO DE PRECEDENTES ANTE A BARREIRA IMPOSTA PELO ARTIGO 1.030 DO CPC ${ }^{1}$
}

\author{
CONSTITUTIONAL COMPLAINT: AN ALTERNATIVE FOR OVERCOMING
} PRECEDENT CONSIDERING THE OBSTACLE IMPOSED BY ARTICLE 1.030 OF THE BRAZILIAN CODE OF CIVIL PROCEDURE

Tatiane Costa de Andrade Mestranda em Direito Processual pela PUC Minas. Graduada em Direito pela Faculdade Mineira de Direito da PUC Minas e Letras pela Faculdade de Letras da UFMG. Servidora pública efetiva do Ministério Público do Trabalho (MPT). Assessora jurídica. Belo Horizonte/MG. E-mail: tatiane.costaandrade@gmail.com

RESUMO: A reclamação constitucional é instituto jurídico tipicamente brasileiro, que surgiu na jurisprudência do STF e ganhou extrema importância ao longo de suas fases históricas, sobretudo a partir de sua codificação no CPC de 2015. Tem como essência a finalidade de preservar a competência dos tribunais e garantir a autoridade de suas decisões. Todavia, no atual contexto de dificuldade de acesso dos jurisdicionados às cortes superiores, por força da redação do art. 1.030 do CPC, apresenta-se como mecanismo de garantia dos sujeitos processuais para instar as cortes superiores a promover a revisão de seus precedentes, evitando-se, com isso, o engessamento do direito pátrio e promovendo a natural e desejada dialeticidade das cortes com seus próprios julgados.

PALAVRAS-CHAVE: Reclamação; Estabilidade; Precedentes; Superação; Dialeticidade.

\footnotetext{
${ }^{1}$ Artigo recebido em 01/03/2019 e aprovado em 16/07/2019.
} 
ABSTRACT: The constitutional complaint is a typically Brazilian legal institute, which emerged in the jurisprudence of the Supreme Court (STF) and gained extreme importance throughout its historical phases, especially since its codification in the Code of Civil Procedure of 2015 (CPC). Its essence is the purpose of preserving the jurisdiction of the courts and ensuring the authority of their decisions. However, in the current context of difficult access of the upper courts, due to the obstacle of art. 1030 of the $\mathrm{CPC}$, is presented as a mechanism to guarantee the procedural subjects to urge the superior courts to promote the revision of their precedents, thereby avoiding the stiffening of the right of the country and promoting the natural and desired dialogue of the courts with their own decisions.

KEY WORDS: Complaint; Stability; Precedents; Overcoming; Dialogue.

\section{INTRODUÇÃO}

Este trabalho tem como objetivo realizar uma breve reflexão sobre a utilidade do instituto da reclamação constitucional, discorrendo sobre como se deu o aumento de sua importância no ordenamento jurídico desde a sua criação, pela jurisprudência do STF, até a sua recente fase de codificação pelo CPC de 2015.

Intenta-se demonstrar que, atualmente, a reclamação constitui relevante ferramenta para o controle da estabilidade da jurisprudência de todos os tribunais, ao mesmo tempo em que se apresenta como garantia de acesso do jurisdicionado aos tribunais superiores, para promover a distinção e a superação de seus precedentes.

Inicialmente, no segundo tópico, propõe-se um apanhado histórico sobre o surgimento e a evolução da reclamação no Brasil, dividindo o seu estudo em fases, a exemplo do que já tem sido feito pelos juristas que se dedicam ao estudo aprofundado desse tema.

O terceiro tópico é dedicado exclusivamente ao trato do direito jurisprudencial, com especial atenção à formação do sistema de precedentes obrigatórios no direito processual brasileiro a partir da inserção das técnicas de padronização decisória instituídas através dos artigos 926 e 927 do CPC. Essa noção é de extrema relevância para compreensão dos novos contornos assumidos pela reclamação em meio ao novo panorama processual. 
Na sequência, discorre-se, no quarto tópico, acerca da importância da reclamação para manter a coesão do sistema de precedentes proposto pelo CPC de 2015. Por fim, no quinto tópico apresenta-se a defesa em prol da utilidade da reclamação como passaporte de acesso do jurisdicionado aos tribunais superiores, tendo em vista a barreira estabelecida pelo artigo 1.030 do CPC, quando o objetivo é, sobretudo, promover a superação dos entendimentos vinculantes do STF e do STJ.

Pretende-se demonstrar, ao final, que a reclamação representa uma das técnicas possíveis para instigar os tribunais superiores a rever o conteúdo e o alcance de seus julgados, de modo a impedir o engessamento do direito jurisprudencial, situação que passa ao largo dos escopos de uma teoria de precedentes e de um modelo constitucional de processo.

\section{HISTÓRICO DA RECLAMAÇÃO CONSTITUCIONAL NO BRASIL}

A reclamação constitucional configura instituto jurídico tipicamente brasileiro 2 e o estudo de sua trajetória histórica é crucial para que se entenda a importância que ele foi alcançando no ordenamento jurídico ao longo dos tempos, sobretudo após a vigência do Código de Processo Civil de 2015.

Inicialmente, importa frisar que a presente reflexão não tem como escopo adentrar às controvérsias doutrinárias e jurisprudenciais existentes acerca da natureza jurídica da reclamação. Com Fredie Didier Jr. e Leonardo Carneiro da Cunha, compreende-se a reclamação como "ação autônoma, de competência originária de tribunal, prevista na Constituição Federal, nas Constituições Estaduais e no CPC, com vistas a obter a preservação de sua competência ou garantir a autoridade de seus julgados ou de seus precedentes obrigatórios”, através da cassação da decisão impugnada3.

Os estudiosos que se dedicaram a esse instituto costumam dividir sua evolução em fases, com finalidade didática, embora o número de fases nem sempre seja coincidente entre eles. Gustavo Azevedo, em obra recente destinada exclusivamente ao estudo da reclamação constitucional, a partir da contribuição de autores como José da Silva Pacheco, Marcelo

2 DANTAS, Marcelo Ribeiro Navarro. A reclamação constitucional no Direito comparado. In: COSTA, Eduardo José da Fonseca; NOGUEIRA, Pedro Henrique Pedrosa (Org.). Reclamação constitucional. Salvador. Salvador: Juspodium, 2013. P.336.

3 DIDIER JR.,Fredie; CUNHA, Leonardo Carneiro. Curso de direito processual civil: meios de impugnação às decisões judiciais e processo nos tribunais. 13. Ed. Salvador: Juspodium, 2016. V.3.p.533-535. 
Rio de Janeiro. Ano 13. Volume 20. Número 3. Setembro a Dezembro de 2019

Periódico Quadrimestral da Pós-Graduação Stricto Sensu em Direito Processual da UERJ

Patrono: José Carlos Barbosa Moreira (in mem.). ISSN 1982-7636. pp. 546-574 www.redp.uerj.br

Navarro Ribeiro Dantas e Leonardo Lins Morato, propõe a divisão histórica desse instituto jurídico em apenas três fases, a saber: a) fase pré-constitucional; b) fase constitucional e c) fase codificada.4Essa é a divisão que se adota também ao longo deste trabalho.

Em linhas gerais, a reclamação constitucional teve sua origem na jurisprudência do Supremo Tribunal Federal (STF), ao longo da década de 19405, sem que houvesse, à época, qualquer previsão legal que autorizasse o seu cabimento. Explica Gustavo Azevedo que o STF utilizou como fundamento para legitimar o uso da reclamação a chamada "teoria dos poderes implícitos", de origem norte-americana. De acordo com essa teoria, quando a Constituição estabelece competências explícitas a determinado órgão ou entidade, ela também confere a ele, ainda que de forma implícita, todos os poderes necessários para exercê-las. No caso, se a Constituição atribui competências ao STF, natural que dela se extraiam também os mecanismos para que a Corte preserve tais competências e faça valer a autoridade de suas decisões6.

Em 1957 o STF positivou o instituto, inserindo-o em seu Regimento Interno, com vistas a afastar as discussões sobre sua legitimidade. Mais tarde, a Constituição de 1967, em seu artigo 115, parágrafo único, alínea "c", reproduzido integralmente pelo artigo 120, parágrafo único, alínea “c”, após a redação dada pela EC 1/69, dispôs que o Regimento Interno do STF estabeleceria o processo e o julgamento dos feitos de sua competência originária ou recursal. Essa redação legitimou a disposição regimental do STF sobre a reclamação constitucional, afastando as polêmicas em torno da (in)constitucionalidade do instituto.

De acordo com a divisão feita por Gustavo Azevedo, a segunda fase (fase constitucional) tem início a partir da Constituição de 1988, quando a reclamação passa a ter

4 "A primeira fase vai desde a apreciação pelo STF das primeiras reclamações até a promulgação da CF. A segunda fase possui como marco inicial a alçada do instituto a nível constitucional (CF, arts. 102, I, 1, e 105, I, f), até 2016. A última fase começa com a vigência do CPC, que regulamenta, no texto codificado, o procedimento, hipóteses de cabimento e competência de todo tribunal para apreciar reclamações." (AZEVEDO, Gustavo. Reclamação constitucional no direito processual civil. Rio de Janeiro: Forense, 2018.p.44-48). A respeito da evolução histórica da reclamação, confira-se também MENDONÇA NETO, Jouberto Uchôa de. A reclamação constitucional no novo código de processo civil. p. 4-6. Disponível em < http://www.esasergipe.org.br/wp-content/uploads/2016/11/A-reclama\%C3\%A7\%C3\%A3o-constitucionalno-Novo-C\%C3\%B3digo-de-Processo-Civil.pdf> Acesso em 11 dez. 2018.

5 A doutrina suscita como marco da reclamação constitucional a Reclamação no 141-SP, Rel.Min. Rocha Lagoa, de 25/1/1942).

6 AZEVEDO, Gustavo. Reclamação constitucional no direito processual civil. Rio de Janeiro: Forense, 2018. p. 54. 
previsão não só no Regimento Interno do STF como também nos artigos 102, I, “l” e 105, I, "f" da Constituição, inaugurando o cabimento da reclamação também perante o Superior Tribunal de Justiça (STJ), recém criado pela Constituição de 1988.

Na sequência, adveio a lei 8.038/90, que instituiu normas procedimentais para os processos perante o Superior Tribunal de Justiça e o Supremo Tribunal Federal, e, em seus artigos 13 a 18 regulamentou o procedimento da reclamação perante essas duas cortes. Os referidos dispositivos foram todos revogados pela Lei $\mathrm{n}^{\circ} 13.105 / 2015$, que instituiu o novo Código de Processo Civil.

Ainda na fase constitucional, sobreveio a edição da EC 45/2004, conhecida popularmente como "reforma do Judiciário", que, dentre suas inúmeras novidades, inseriu na Constituição Federal o artigo 103-A, dispondo sobre a possibilidade de edição de Súmula Vinculante pelo STF. O parágrafo $3^{\circ}$ do referido dispositivo foi quem tratou sobre a reclamação constitucional, exatamente para prever o cabimento do instituto contra ato administrativo ou decisão judicial que contrarie ou que mal aplique o conteúdo de súmula vinculante7.

A partir de então, o número de reclamações no STF aumentou consideravelmente, pois o instituto que, até 2004 , era praticamente desconhecido, parece ter se tornado familiar aos profissionais do direito, atentos à importância das súmulas vinculantes. Para se ter uma ideia, tal como informa Gustavo Azevedo, com base em estatística disponível na página do STF na internet, em 2004, antes da vigência da EC/2004 foram distribuídas nesse órgão apenas 491 reclamações, passando para 933 em 2005 e para 2.353 em 20148. Em 2018, a estatística aponta a distribuição de 3.295 reclamações na Corte9. No STJ, os números apontam para a distribuição de 456 reclamações em 2009, 1.247 em 2010, chegando a 6.947

7 Art. 103-A.[...]

$[\ldots]$

$\S 3^{\text {o: }}$ Do ato administrativo ou decisão judicial que contrariar a súmula aplicável ou que indevidamente a aplicar, caberá reclamação ao Supremo Tribunal Federal que, julgando-a procedente, anulará o ato administrativo ou cassará a decisão judicial reclamada, e determinará que outra seja proferida com ou sem a aplicação da súmula, conforme o caso.

8 AZEVEDO, Gustavo. Reclamação constitucional no direito processual civil. Rio de Janeiro: Forense, 2018. p. 54.

9Dados disponíveis em http://portal.stf.jus.br/textos/verTexto.asp?servico=estatistica\&pagina=pesquisaClasse. Acesso em 12 dez. 2018. 
em 201410, vindo a cair para 2.014 em 201711, ano da última atualização estatística nesse órgão até a presente data12.

O advento CPC/2015, com redação alterada pela lei no 13.256/2016, dá ensejo à fase codificada da reclamação, antes mesmo do início de vigência do referido Código. O instituto passou a ser objeto de disposição dos artigos 988 a 993 do Novo CPC, em que se encontram regulados a legitimidade para ajuizar, as hipóteses de cabimento, a competência e o procedimento. Isso, todavia, não retira dos regimentos internos a atribuição de regulamentar, no âmbito do respectivo tribunal, qual o órgão competente para apreciar, a atribuição da relatoria e as regras de prevenção13.

Em relação à competência, o que ocorreu foi a sua ampliação, haja vista que o CPC não deixa dúvidas de que a reclamação agora é cabível em qualquer tribunal, não mais se restringindo ao STF e ao STJ, conforme dispõe o art. 988, § 1º do CPC14. A propósito, esse entendimento se mostra mais condizente com a razão de ser da reclamação, cujo fundamento, como se viu, se encontra na teoria dos poderes implícitos. Na linha dessa teoria, é viável que todos os tribunais possam lançar mão de um instrumento para preservar sua competência e a autoridade de suas decisões.

Ampliam-se também as hipóteses de cabimento, na medida em que foram acrescentadas novas técnicas de formação de precedente obrigatório no novo Código, a exemplo do Incidente de Assunção de Competência (IAC) e do Incidente de Resolução de Demandas Repetitivas (IRDR), passando a reclamação a ser admitida nas seguintes situações: I) para preservar a competência do tribunal; II) para garantir a autoridade das decisões do tribunal; III) para garantir a observância de enunciado de súmula vinculante e de decisão do Supremo Tribunal Federal em controle concentrado de constitucionalidade; e IV) para garantir a observância de acórdão proferido em julgamento de incidente de resolução de demandas repetitivas ou de incidente de assunção de competência.

10 AZEVEDO, Gustavo. Reclamação constitucional no direito processual civil. Rio de Janeiro: Forense, 2018. p. 62.

11 Dado disponível em http://www.stj.jus.br/webstj/Processo/Boletim/sumario.asp. Acesso em 12 dez. 2018. 12 A data em referência é 12-12-2018.

13 DIDIER JR.,Fredie; CUNHA, Leonardo Carneiro. Curso de direito processual civil: meios de impugnação às decisões judiciais e processo nos tribunais. 13. Ed. Salvador: Juspodium, 2016. V.3. p. 532.

14 Art. 988 [...]

$\S$ 1o A reclamação pode ser proposta perante qualquer tribunal, e seu julgamento compete ao órgão jurisdicional cuja competência se busca preservar ou cuja autoridade se pretenda garantir. 
Esse acréscimo das hipóteses de cabimento da reclamação, em meio ao contexto de criação de um sistema de precedentes a partir do CPC de 2015, elevou sobremaneira a importância do instituto, que, conforme se abordará nos próximos tópicos, transformou-se em um importante meio de controle da estabilidade das decisões e de garantia da segurança jurídica, premissas bastante caras para o Novo CPC.

\section{NOVOS RUMOS DO DIREITO JURISPRUDENCIAL A PARTIR DO CPC DE}

\section{5}

A preocupação com a segurança jurídica e com a eficiência e celeridade na prestação jurisdicional sempre foi tema recorrente ao se falar em reformas legislativas do sistema de direito processual de qualquer país, ainda que, por vezes, tais reformas sejam, em verdade, reflexo do que se passa na ordem econômica.15

No Brasil, país de tradição legiferante e codificadora, denominada civil law, essa preocupação vem se acentuando, sobretudo a partir do advento da Constituição de 1988, quando teve início por aqui o movimento de constitucionalização do direito, decorrente do fenômeno que se convencionou chamar de "neoconstitucionalismo."16

Trata-se de um fenômeno que despontou na Europa ocidental após o término da II Guerra Mundial e levou os teóricos do Direito a refletirem sobre premissas do positivismo jurídico clássico e a repensar o excesso de formalismo decorrente da supremacia das regras sobre os princípios. A experiência vivenciada com os totalitarismos e a premente necessidade de se garantir a efetividade dos direitos fundamentais impulsionou o fortalecimento das Constituições, a reaproximação do direito e da moral e, sobretudo, o reconhecimento da força normativa dos princípios jurídicos, o que, consequentemente, ocasionou uma radical mudança nas teorias da argumentação.

15 Para uma maior compreensão sobre o que está por trás das reformas processuais, recomenda-se a leitura da consistente obra de NUNES, Dierle José Coelho. Processo jurisdicional democrático: uma análise crítica das reformas processuais. Curitiba: Juruá, 2012. Especificamente sobre o sistema processual brasileiro, vide capítulo 5 da referida obra, p.141-176.

16 Para um maior esclarecimento sobre o que consiste o "neoconstitucionalismo", recomenda-se a leitura de SARMENTO, Daniel. O neoconstitucionalismo no Brasil: riscos e possibilidades. Rio de Janeiro, 2009. Texto disponível em <http://www.dsarmento.adv.br/content/3-publicacoes/16-o-neoconstitucionalismo-no-brasil$\underline{\text { riscos-e-possibilidades/o-neoconstitucionalismo-no-brasil.riscos-e-possibilidades-daniel-sarmento.pdf }>}$ Acesso em 13. Dez. 2018. 
No contexto brasileiro, em que tais tendências foram tardiamente recepcionadas, a Constituição deixou de ser um mero programa, adquirindo força normativa, elevando os direitos fundamentais a normas de eficácia imediata, além de prever mecanismos sérios de controle de constitucionalidade. Paralelamente a isso, assiste-se a um exacerbado fortalecimento do Poder Judiciário, que adquire maior liberdade interpretativa das normas, especialmente através da aplicação da técnica da ponderação de princípios, e passa a ser palco, inclusive, da judicialização de políticas públicas e de um crescente ativismo judicial. Essa nova realidade contribuiu para o fortalecimento do direito jurisprudencial no Brasil, que, conforme bem pontuado por Aurélio Viana e Dierle Nunes, já era utilizado desde o tempo do direito colonial17, sobretudo em face da inevitável e progressiva convergência entre as tradições jurídicas do civil law e do common law18.

A partir do cenário da constitucionalização, o direito jurisprudencial ganhou mais forças, mas sem uma necessária sistematização. A amplitude interpretativa e a criatividade conferida aos juízes nesse contexto acarretaram a instauração de um verdadeiro caos no âmbito jurisprudencial, pois os tribunais em geral não se preocuparam tanto em estabilizar seus julgados, vindo a produzir uma série de decisões incoerentes, por vezes pautadas em questões políticas, deixando pairar bastante insegurança jurídica no sistema.

As tentativas de racionalização da jurisprudência, por meio de reformas pontuais, sobretudo a partir da década de 1990, não foram suficientes para trazer maior padronização e coerência às decisões judiciais. Dentre as legislações que se seguiram com propósito de uniformização de jurisprudência, a exemplo das leis 8.038/1990, 9.139/1995, 9.756/1998, 10.352/2001 e 10.522/2002, merece destaque a EC 45/2004, que, como já dito alhures, trouxe a possibilidade de edição de súmulas vinculantes pelo STF, importante mecanismo de contenção da interpretação do ordenamento jurídico pelos demais órgãos jurisdicionais e pela própria administração pública. A esta se seguiram as leis 11.276/2006, 11.417/2006, 11.418/2006, 11.672/2008, 12.322/2010 e 12.844/2013, todas com o mesmo propósito de fortalecer o papel da jurisprudência no sistema jurídico brasileiro.19

17 VIANA, Aurélio; NUNES, Dierle. Precedentes: a mutação no ônus argumentativo. Rio de Janeiro: Forense,2018.p.178-181.

18 Acerca das razões e circunstâncias em que ocorre a convergência entre as tradições civil law e common law, vide VIANA, Aurélio; NUNES, Dierle. Precedentes: a mutação no ônus argumentativo. Rio de Janeiro: Forense, 2018.p.149-175.

19 VIANA, Aurélio; NUNES, Dierle. Precedentes: a mutação no ônus argumentativo. Rio de Janeiro: Forense,2018. p.187-190. 
A iniciativa de estruturar um verdadeiro sistema de precedentes no Brasil somente veio a correr, todavia, a partir do CPC de 2015. Isso porque, até então, o que se presenciou a partir da edição das referidas leis ordinárias acima apontadas, com ressalva feita à EC 45/2004, foi tão-somente uma tentativa incipiente de incentivar a aplicação do direito jurisprudencial, tornando a jurisprudência mais persuasiva, e não propriamente a formação de um sistema organizado de padronização decisória.

Conforme salientam Humberto Theodoro Jr., Dierle Nunes, Alexandre Bahia e Flávio Pedron, a formação de precedentes implica a observância da "parametricidade que induz a aplicação dos fundamentos determinantes de casos passados ao caso em julgamento, mas permitindo distinções quando seja possível a demonstração de diferenças.”.20

Ao contrário disso, no Brasil, ementas de julgados e enunciados de súmulas vêm, há muito, sendo utilizados de forma abstrata para fundamentar os casos sob julgamento, sem que se faça qualquer remissão às situações fáticas que lhes deram ensejo, nem se explique qual a semelhança dos referidos julgados paradigma com a situação fática em análise. Não foi outra a razão pela qual o CPC de 2015 , em seu artigo $489, \S 1^{\circ}, \mathrm{V}$, considerou como decisão não fundamentada aquela que "se limitar a invocar precedente ou enunciado de súmula, sem identificar seus fundamentos determinantes nem demonstrar que o caso sob julgamento se ajusta àqueles fundamentos.”.

Os artigos 926 e 927 do CPC, por sua vez, acomodam as técnicas para a formação de precedentes que, após consolidados deverão necessariamente vincular os demais órgãos

20 THEODORO JÚNIOR, Humberto et al. Novo CPC: fundamentos e sistematização.3. ed. Rio de Janeiro: Forense, 2016. p. 393. Ainda sobre a conceituação de precedentes, confira-se trecho extraído do glossário da obra de Aurélio Viana e Dierle Nunes: "De modo mais singelo, o precedente é compreendido como uma decisão anterior que servirá de base para a decisão de um caso presente ou futuro. Contudo, essa concepção extremamente simplória acaba se tornando imprestável tendo em vista a necessidade de se debruçar sobre aquilo que, exatamente, no precedente, servirá para outros casos futuros e ainda quais os limites de invocação de uma decisão anterior como padrão decisório a ser observado. O precedente judicial, em nossa visão, deve ser visto como starting points ou principium, de tal modo que não é possível concordar com um fechamento argumentativo quanto ao uso de precedentes judiciais. Cada precedente possui ou deveria possuir uma ratio decidendi, isto é, um motivo determinante. Não é incomum se deparar, entretanto, com um precedente que possua mais de uma ratio decidendi, o que torna o método comparativo bastante complexo. Há necessidade de que se faça uma comparação entre os fatos operativos dos casos, inaugurando técnicas de analogias e contraanalogias exatamente para que seja testada a adequação de uso de uma decisão passada. Pensamos que o uso do direito jurisprudencial, por expressa disposição enunciativa, guarda conexão com a teoria dworkiniana da integridade e coerência do direito. Dito de outro modo, essa proposta interpretativa repercute em todos os enunciados do CPC/2015 que recomendam ou resvalam de qualquer maneira na aplicação do direito a partir de casos passados." (VIANA, Aurélio; NUNES, Dierle. Precedentes: a mutação no ônus argumentativo. Rio de Janeiro: Forense, 2018. p.414). 
jurisdicionais.21Isso porque a nova legislação impõe, a partir da redação do caput do artigo 926, que os tribunais uniformizem sua jurisprudência, mantendo-a estável, íntegra e coerente. Busca-se com isso ampliar o caráter vinculante das decisões, limitando ao máximo as possibilidades de interpretação para casos repetitivos, com vistas a colocar fim a tamanha insegurança jurídica que assola os tribunais pátrios e deixam os jurisdicionados perplexos perante a falta de isonomia de entendimento em casos que se assemelham.

Consequentemente, as referidas técnicas constantes dos artigos 926 e 927 geram impacto ao longo de outros dispositivos do CPC, a exemplo dos artigos 311, II (concessão de tutela de evidência quando as alegações de fato podem ser comprovadas por documentos e há tese firmada em julgamento de casos repetitivos ou súmula vinculante), 332 (improcedência liminar do pedido que contraria precedente obrigatório), 489, § $1^{\circ}$ (exigência de que o julgador realize a comparação entre os casos para que se considere fundamentada decisão baseada em súmula, jurisprudência ou precedente obrigatório) e 932, IV e V (prerrogativas do relator, que pode dar ou negar provimento a recurso, conforme esteja ou não em conformidade com precedente obrigatório). Esse fato demonstra que todo o Código se mostra voltado para a preocupação em reduzir o grau de incoerência dentro do sistema,

21 Art. 926. Os tribunais devem uniformizar sua jurisprudência e mantê-la estável, íntegra e coerente.

$\S 1$ o Na forma estabelecida e segundo os pressupostos fixados no regimento interno, os tribunais editarão enunciados de súmula correspondentes a sua jurisprudência dominante.

$\S 20$ Ao editar enunciados de súmula, os tribunais devem ater-se às circunstâncias fáticas dos precedentes que motivaram sua criação.

Art. 927. Os juízes e os tribunais observarão:

I - as decisões do Supremo Tribunal Federal em controle concentrado de constitucionalidade;

II - os enunciados de súmula vinculante;

III - os acórdãos em incidente de assunção de competência ou de resolução de demandas repetitivas e em julgamento de recursos extraordinário e especial repetitivos;

IV - os enunciados das súmulas do Supremo Tribunal Federal em matéria constitucional e do Superior Tribunal de Justiça em matéria infraconstitucional;

V - a orientação do plenário ou do órgão especial aos quais estiverem vinculados.

$\S 1$ o Os juízes e os tribunais observarão o disposto no art. 10 e no art. 489 , §1o, quando decidirem com fundamento neste artigo.

$\S 2 \mathrm{o}$ A alteração de tese jurídica adotada em enunciado de súmula ou em julgamento de casos repetitivos poderá ser precedida de audiências públicas e da participação de pessoas, órgãos ou entidades que possam contribuir para a rediscussão da tese.

§ 3o Na hipótese de alteração de jurisprudência dominante do Supremo Tribunal Federal e dos tribunais superiores ou daquela oriunda de julgamento de casos repetitivos, pode haver modulação dos efeitos da alteração no interesse social e no da segurança jurídica.

$\S 4$ o A modificação de enunciado de súmula, de jurisprudência pacificada ou de tese adotada em julgamento de casos repetitivos observará a necessidade de fundamentação adequada e específica, considerando os princípios da segurança jurídica, da proteção da confiança e da isonomia.

$\S 50$ Os tribunais darão publicidade a seus precedentes, organizando-os por questão jurídica decidida e divulgando-os, preferencialmente, na rede mundial de computadores. 
reduzindo as possibilidades interpretativas para conferir integridade à jurisprudência e incentivando o respeito à tradição institucional dos tribunais.

Espera-se com essas novas regras uma mudança de postura tanto das partes quanto dos órgãos jurisdicionais no trato do direito jurisprudencial, pois ambos deverão agora dialogar com os precedentes, realizando um verdadeiro cotejo analítico entre os casos que lhes deram origem e o caso concreto que está sob julgamento. Não há mais espaço para a aplicação descontextualizada de enunciados de súmulas e ementas de julgados, o que acarreta um aumento da responsabilidade argumentativa de todos sujeitos processuais. $22 \mathrm{O}$ afastamento das decisões vinculantes, seja por meio da distinção entre os casos em comparação, seja por meio da superação dos fundamentos determinantes de uma dada decisão, requer um maior esforço tanto na elaboração da petição inicial pelo advogado, quanto na fundamentação da decisão por parte do julgador, na direção do que determina o art. $489, \S 1^{\circ}, \mathrm{V}$, do $\mathrm{CPC} 23$.

Feitas estas breves considerações sobre a nova sistemática de precedentes apresentada pelo CPC de 2015, passa-se a discorrer sobre a importância assumida pelo instituto da reclamação constitucional em meio a esse novo cenário.

\section{IMPORTÂNCIA DA RECLAMAÇÃO NO SISTEMA DE PRECEDENTES}

Conforme se apontou ao se apresentar a trajetória histórica da reclamação, o instituto teve origem na jurisprudência do STF, a partir da aplicação da teoria norte-americana dos poderes implícitos. Isso porque o STF necessitava, naquele momento, de uma ferramenta hábil para fazer preservar a sua competência e impor a autoridade de suas decisões perante os inúmeros órgãos jurisdicionais brasileiros.

22 VIANA, Aurélio; NUNES, Dierle. Precedentes: a mutação no ônus argumentativo. Rio de Janeiro: Forense, 2018.p.301-399.

23 Art. 489 [...]

$\S 1$ o Não se considera fundamentada qualquer decisão judicial, seja ela interlocutória, sentença ou acórdão, que:

$[\ldots]$

V - se limitar a invocar precedente ou enunciado de súmula, sem identificar seus fundamentos determinantes nem demonstrar que o caso sob julgamento se ajusta àqueles fundamentos; 
Já na fase codificada da reclamação, o CPC de 2015 ampliou a competência para apreciação do instituto, estendendo sua possibilidade de cabimento perante todos os tribunais. Esse fato somado ao empenho na busca por maior padronização decisória, o que se consolida com a sistematização dos precedentes no novo Código, transformou a reclamação em um dos mecanismos mais importantes de controle da aplicação dos precedentes obrigatórios e de manutenção da integridade e coerência do sistema jurídico.

O CPC ampliou também as hipóteses de cabimento da reclamação anteriormente previstas na Constituição, em seus artigos 102, “l”, 105, “f” e 103-A, § 3, devido ao surgimento das novas técnicas surgidas para formação de precedentes obrigatórios. Assim, na atual sistemática, a reclamação continua se prestando à finalidade tanto de preservar a competência dos tribunais quanto de garantir a autoridade de suas decisões. Porém, neste último caso, conforme ensinam Fredie Didier Jr. e Leonardo Carneiro da Cunha, o CPC explicita, em rol exaustivo, todas as decisões que poderão ter a autoridade garantida através da reclamação, a saber: a) enunciado de súmula vinculante e decisão do STF em controle concentrado de constitucionalidade; b) precedente proferido em julgamento de Incidente de Resolução de Demandas Repetitivas (IRDR) ou em Incidente de Assunção de Competência (IAC); e c) acórdão proferido em recurso extraordinário com repercussão geral reconhecida ou em recurso repetitivo, após esgotadas as vias ordinárias (conforme artigo 988, § 5º II, do CPC). 24

Sob essa perspectiva, não é difícil perceber que a reclamação, ao lado dos recursos, se tornou peça chave para garantia da observância dos precedentes obrigatórios formados sob a égide do artigo 927 do CPC. A reclamação é cabível tanto em decorrência da relutância na aplicação de um precedente obrigatório quanto em razão de sua aplicação equivocada, em decorrência de um erro de interpretação, seja por órgão jurisdicional, seja por entidade da administração pública (art. 988, § $4^{\circ}$, do CPC)25. Sua importância é tamanha que Gustavo

24 DIDIER JR., Fredie; CUNHA, Leonardo Carneiro. Curso de direito processual civil: meios de impugnação às decisões judiciais e processo nos tribunais. 13. Ed. Salvador: Juspodium, 2016. V.3. p. 540.

25 Art. 988. Caberá reclamação da parte interessada ou do Ministério Público para:

I - preservar a competência do tribunal;

II - garantir a autoridade das decisões do tribunal;

III - garantir a observância de decisão do Supremo Tribunal Federal em controle concentrado de constitucionalidade;

III - garantir a observância de enunciado de súmula vinculante e de decisão do Supremo Tribunal Federal em controle concentrado de constitucionalidade; 
Azevedo, seguindo o escólio de Marcelo Navarro Ribeiro Dantas, chega a equipará-la aos remédios constitucionais, ao lado do habeas corpus e do mandado de segurança ${ }^{26}$

Por meio da reclamação, portanto, o jurisdicionado tem a oportunidade de demonstrar se houve negação de aplicação de um dado precedente obrigatório ou equívoco em sua interpretação. O tribunal respectivo, de seu turno, poderá analisar a controvérsia e verificar se ocorreu distinção equivocada por parte da autoridade prolatora da decisão impugnada ou se a autoridade deixou de fazer a devida distinção (distinguishing) quando esta se mostrava necessária.27 É possível ainda, através do julgamento da reclamação, que o tribunal reveja o seu próprio precedente, promovendo a sua superação (overruling) 28 após perceber que houve mudanças no cenário social.

Essa possibilidade de realização da distinção e da superação de precedentes pelos tribunais ficou evidente após o julgamento da Rcl 4.374/PE no STF29, cuja ementa ora se transcreve, por oportuno e necessário aos desígnios deste trabalho, com destaques que não constam do original:

Benefício assistencial de prestação continuada ao idoso e ao deficiente. Art. 203, V, da Constituição. A Lei de Organização da Assistência Social (LOAS), ao regulamentar o art. 203, V, da Constituição da República, estabeleceu critérios para que o benefício mensal de um salário mínimo fosse concedido aos portadores de deficiência e aos idosos que comprovassem não

IV - garantir a observância de enunciado de súmula vinculante e de precedente proferido em julgamento de casos repetitivos ou em incidente de assunção de competência.

IV - garantir a observância de acórdão proferido em julgamento de incidente de resolução de demandas repetitivas ou de incidente de assunção de competência;

[...]

§ 4o As hipóteses dos incisos III e IV compreendem a aplicação indevida da tese jurídica e sua não aplicação aos casos que a ela correspondam.

26 “A reclamação equipara-se - em valor e relevância - no sistema jurídico como remédio constitucional, ao habeas corpus e ao mandado de segurança. Cada um com sua finalidade. A reclamação contribui para o bom funcionamento do Poder Judiciário. É útil para que os juízes tratem isonomicamente os jurisdicionados, ao forçá-los a observarem os precedentes obrigatórios. É uma ação constitucional voltada à proteção das competências dos tribunais e garantia da autoridade de seus julgados." (AZEVEDO, Gustavo. Reclamação constitucional no direito processual civil. Rio de Janeiro: Forense, 2018.p.88).

27 Dá-se o nome de distinção (distinguish ou distinguishing) à técnica processual empregada no raciocínio por precedentes, através da qual se realizam comparações, analogias e contra-analogias entre situações, fatos hipóteses, qualidades e atributos, buscando-se compreender se determinado caso anterior deve servir de orientação para a decisão (conforme VIANA, Aurélio; NUNES, Dierle. Precedentes: a mutação no ônus argumentativo. Rio de Janeiro: Forense, 2018.p 383).

28 Denomina-se overruling a técnica de superação do precedente, ou, de outro modo, a substituição ou modificação dos fundamentos determinantes (ratio decidendi) anterior (conforme VIANA, Aurélio; NUNES, Dierle. Precedentes: a mutação no ônus argumentativo. Rio de Janeiro: Forense, 2018.p 414).

29 BRASIL, Supremo Tribunal Federal, Plenário, Rcl 4374/PE, Rel. Min. Gilmar Mendes, j. 18//2013, Dje 4/9/2013. 
possuir meios de prover a própria manutenção ou de tê-la provida por sua família. 2. Art. $20, \S 3^{\circ}$ da Lei 8.742/1993 e a declaração de constitucionalidade da norma pelo Supremo Tribunal Federal na ADI 1.232. Dispõe o art. 20, § $3^{\circ}$, da Lei $8.742 / 93$ que "considerase incapaz de prover a manutenção da pessoa portadora de deficiência ou idosa a família cuja renda mensal per capita seja inferior a 1/4 (um quarto) do salário mínimo". O requisito financeiro estabelecido pela lei teve sua constitucionalidade contestada, ao fundamento de que permitiria que situações de patente miserabilidade social fossem consideradas fora do alcance do benefício assistencial previsto constitucionalmente. Ao apreciar a Ação Direta de Inconstitucionalidade 1.232-1/DF, o Supremo Tribunal Federal declarou a constitucionalidade do art. 20, $\S 3^{\circ}$, da LOAS. 3. Reclamação como instrumento de (re)interpretação da decisão proferida em controle de constitucionalidade abstrato. Preliminarmente, arguido o prejuízo da reclamação, em virtude do prévio julgamento dos recursos extraordinários 580.963 e 567.985 , o Tribunal, por maioria de votos, conheceu da reclamação. O STF, no exercício da competência geral de fiscalizar a compatibilidade formal e material de qualquer ato normativo com a Constituição, pode declarar a inconstitucionalidade, incidentalmente, de normas tidas como fundamento da decisão ou do ato que é impugnado na reclamação. Isso decorre da própria competência atribuída ao STF para exercer o denominado controle difuso da constitucionalidade das leis e dos atos normativos. A oportunidade de reapreciação das decisões tomadas em sede de controle abstrato de normas tende a surgir com mais naturalidade e de forma mais recorrente no âmbito das reclamações. É no juízo hermenêutico típico da reclamação - no "balançar de olhos" entre objeto e parâmetro da reclamação - que surgirá com maior nitidez a oportunidade para evolução interpretativa no controle de constitucionalidade. Com base na alegação de afronta a determinada decisão do STF, o Tribunal poderá reapreciar e redefinir o conteúdo e o alcance de sua própria decisão. E, inclusive, poderá ir além, superando total ou parcialmente a decisão-parâmetro da reclamação, se entender que, em virtude de evolução hermenêutica, tal decisão não se coaduna mais com a interpretação atual da Constituição. 4. Decisões judiciais contrárias aos critérios objetivos preestabelecidos e Processo de inconstitucionalização dos critérios definidos pela Lei 8.742/1993. A decisão do Supremo Tribunal Federal, entretanto, não pôs termo à controvérsia quanto à aplicação em concreto do critério da renda familiar per capita estabelecido pela LOAS. Como a lei permaneceu inalterada, elaboraram-se maneiras de contornar o critério objetivo e único estipulado pela LOAS e avaliar o real estado de miserabilidade social das famílias com entes idosos ou deficientes. Paralelamente, foram editadas leis que estabeleceram critérios mais elásticos para concessão de outros benefícios assistenciais, tais como: a Lei 10.836/2004, que criou o Bolsa Família; a Lei 10.689/2003, que instituiu o Programa Nacional de Acesso à Alimentação; a Lei 10.219/01, que criou o Bolsa Escola; a Lei 9.533/97, que autoriza o Poder Executivo a conceder apoio 
financeiro a municípios que instituírem programas de garantia de renda mínima associados a ações socioeducativas. O Supremo Tribunal Federal, em decisões monocráticas, passou a rever anteriores posicionamentos acerca da intransponibilidade dos critérios objetivos. Verificou-se a ocorrência do processo de inconstitucionalização decorrente de notórias mudanças fáticas (políticas, econômicas e sociais) e jurídicas (sucessivas modificações legislativas dos patamares econômicos utilizados como critérios de concessão de outros benefícios assistenciais por parte do Estado brasileiro). 5. Declaração de inconstitucionalidade parcial, sem pronúncia de nulidade, do art. $20, \S 3^{\circ}$, da Lei 8.742/1993. 6. Reclamação constitucional julgada improcedente. (Rcl 4374, Relator(a): Min. GILMAR MENDES, Tribunal Pleno, julgado em 18/04/2013, ACÓRDÃO ELETRÔNICO DJe-173 DIVULG 03-09-2013 PUBLIC 04-09-2013)

Nesse referido caso, a Reclamação foi ajuizada pelo Instituto Nacional do Seguro Social (INSS) contra decisão proferida pela Turma Recursal dos Juizados Especiais Federais do Estado de Pernambuco, que teria violado decisão proferida pelo STF na ADI 1.232/DF. No julgamento dessa Ação Direta de Inconstitucionalidade, o STF havia declarado a constitucionalidade do $\S 3^{\circ}$ do artigo 20 da Lei 8.742/1993, que estabelece critérios para concessão o benefício assistencial previsto no artigo 203, V, da Constituição. De acordo com a autarquia reclamante, a parte reclamada teria afastado o requisito legal expresso no dispositivo constitucional, violando, pois, o precedente firmado em controle concentrado de constitucionalidade.

Sem nos adentrarmos aos pormenores do caso concreto subjacente à Rcl 4374/PE, o que importa para esta reflexão é que, ao julgar esta reclamação, o Relator, Ministro Gilmar Mendes, ao fundamento de ocorrência de mutação constitucional, revogou o acórdão proferido na ADI 1.232, decretando inconstitucional o art. 20, $\S 3^{\circ}$, da Lei $\mathrm{n}^{\circ}$ 8.742/1993, julgando, ao final, improcedente a reclamação. Com isso, conforme bem explica Gustavo Azevedo, foi possível extrair do julgado duas importantes razões de decidir, a saber:

(1) é possível na reclamação, na condição de ação protetiva da ordem constitucional, a reinterpretação, distinção e superação de razões de decidir de acórdão proferido em ação de controle concentrado de constitucionalidade; e

(2) a reclamação pode implicar revogação do acórdão de ação de controle concentrado de constitucionalidade, nos casos de mutação constitucional e processo de inconstitucionalização de norma, nesse caso, a reclamação possui eficácia constitutiva 
negativa, pois elimina do mundo jurídico (desfaz, desconstitui, quebra, extirpa...) norma jurídica concreta no acórdão parâmetro da demanda reclamatória30.

Seguindo a linha adotada por Gustavo Azevedo, entendemos também que o STF, bem como os demais tribunais, pode realizar a superação de seus precedente obrigatório no âmbito do julgamento de reclamação, oportunidade em que se revisitam os motivos determinantes das decisões com certo distanciamento e em cotejo com a nova ordem social que se apresenta.31Contudo, nesse caso, há que se observar a necessidade de estrita observância do devido processo legal, respeitando-se a competência dos órgãos para formação dos precedentes, a abertura do efetivo contraditório às partes, a publicidade e a eventual necessidade de modulação dos efeitos da decisão.

Gustavo Azevedo pondera, todavia, que a possibilidade de haver distinção e superação do precedente obrigatório em sede de reclamação é tão-somente consequência do ajuizamento da ação reclamatória, não podendo a aplicação das referidas técnicas processuais serem objeto do pedido da reclamação feito pelo jurisdicionado, por entender que esta opção não consta do rol taxativo do artigo 988 do CPC.32 Ousamos discordar desse posicionamento, pelas razões que serão expostas no próximo tópico.

\section{RECLAMAÇÃO COMO TÉCNICA PARA A DISTINÇÃO E SUPERAÇÃO DE PRECEDENTES ANTE A BARREIRA IMPOSTA PELO ART. 1.030 DO CPC}

Conforme já se abordou, a reclamação foi se transformando, ao longo de sua história, em importante garantia para a integridade e coerência do direito jurisprudencial no Brasil, sobretudo após a edição do CPC de 2015, quando houve a organização de um verdadeiro sistema de precedentes. $\mathrm{O}$ escopo dessa nova estrutura processual é trazer maior estabilidade à jurisprudência, por meio de um incremento na padronização decisória, mas sem que se promova, é claro, o engessamento do Direito. Para que se evite isso, o próprio ordenamento

30 AZEVEDO, Gustavo. Reclamação constitucional no direito processual civil. Rio de Janeiro: Forense, 2018.p 197.

31 Com opinião contrária, cite-se BECKER, Rodrigo; TRIGUEIRO, Victor. Reclamação Constitucional para superação de precedentes. Jota Info, 8/12/2016. Disponível em < https://www.jota.info/opiniao-eanalise/colunas/coluna-cpc-nos-tribunais/reclamacao-constitucional-para-superacao-de-precedentes-

08122016> Acesso em 17-12-2018.

32 AZEVEDO, Gustavo. Reclamação constitucional no direito processual civil. Rio de Janeiro: Forense, 2018.p 202. 
jurídico, como se viu, apresenta técnicas para que se faça a distinção dos casos concretos em relação ao caso que embasa um precedente obrigatório (distinguishing) ou para que se promova a superação de determinado precedente (overruling), quando este não mais se adapta ao contexto social ou à ordem jurídica vigente (art. 927, § $4^{\circ}$, do CPC).33

A superação e a distinção tanto podem partir dos próprios órgãos jurisdicionais, ao tecerem seus julgados, momento em que dialogam efetivamente com o sistema de precedentes, quanto podem ser provocadas pelos jurisdicionados, a partir da petição inicial, caso a pretensão seja contrária a determinado precedente obrigatório, ou por meio da interposição de recursos. Esta última opção tem se mostrado mais comum, na medida em que é perante os tribunais que os precedentes obrigatórios se formam. Faz parte da própria dinâmica do raciocínio através de precedentes, portanto, que haja constante dialeticidade entre os jurisdicionados e os tribunais, a ponto de que estes órgãos, quando convencidos, modifiquem entendimentos anteriormente firmados em seus precedentes.

Esse pode até parecer o melhor dos mundos no âmbito de um processo de base democrática, mas não é o cenário que se tem apresentado no âmbito dos tribunais superiores brasileiros. Estas cortes, mais preocupadas em conter o aumento do volume de demandas que chegam para sua apreciação, têm ignorado a dinâmica inerente ao sistema de precedentes e se encontram agora praticamente blindadas contra a subida de recursos excepcionais quando já existe precedente obrigatório sobre o objeto da controvérsia. A blindagem, que antes já fazia parte do entendimento jurisprudencial do STF e do STJ, tornou-se legalmente possível a partir da alteração do artigo 1.030 do CPC, com redação dada pela Lei $\mathrm{n}^{\circ}$ $13.256 / 2016$.

A redação original do CPC de 2015 continha previsão de que o juízo de admissibilidade dos recursos destinados aos tribunais superiores fosse realizado tão somente pelos próprios tribunais superiores ${ }^{34}$, dispensando o juízo provisório previsto na sistemática

\footnotetext{
33 Art. $927[\ldots]$

[...]

§ 4o A modificação de enunciado de súmula, de jurisprudência pacificada ou de tese adotada em julgamento de casos repetitivos observará a necessidade de fundamentação adequada e específica, considerando os princípios da segurança jurídica, da proteção da confiança e da isonomia.

34 Essa previsão vinha contida na redação original do artigo 1.030, dada pela Lei 13.105/2015, que, de forma simplória, dispunha:

Art. 1.030. Recebida a petição do recurso pela secretaria do tribunal, o recorrido será intimado para apresentar contrarrazões no prazo de 15 (quinze) dias, findo o qual os autos serão remetidos ao respectivo tribunal superior.
} 
do CPC de 1973, em seu antigo artigo 542, $\S 11^{\circ} .{ }^{35}$ Com isso, tornar-se-ia desnecessária a interposição de inúmeros agravos nos tribunais locais, para promover o destrancamento dos recursos excepcionais inadmitidos. Esse intento, todavia, não vingou.

O temor dos ministros do STF e do STJ em relação a um possível aumento desenfreado da subida de recursos excepcionais a essas cortes, a partir da pretensa extinção do duplo juízo de admissibilidade recursal, gerou pressão política sobre as casas legislativas ${ }^{36}$, o que acabou culminando na publicação da Lei 13.256, de 4 de fevereiro de 2016, que alterou disposições do Novo CPC antes do início de sua vigência.

Dentre as alterações promovidas pela referida legislação, destaca-se a inteira modificação do conteúdo do artigo 1.030 do CPC, que trouxe de volta a necessidade de um juízo provisório de admissibilidade dos recursos especial e extraordinário pelo tribunal local (art. 1.030, V, do CPC)37. Além disso, o dispositivo legal conferiu ao presidente ou ao vice-

Parágrafo único. A remessa de que trata o caput dar-se-á independentemente de juízo de admissibilidade. 35 Art. 542. Recebida a petição pela secretaria do tribunal, será intimado o recorrido, abrindo-se-lhe vista, para apresentar contra-razões.

$\S 1^{\circ}$ - Findo esse prazo, serão os autos conclusos para admissão ou não do recurso, no prazo de 15 (quinze) dias, em decisão fundamentada.

36 Para um maior aprofundamento sobre as discussões que culminaram na elaboração da Lei no ${ }^{\circ} 13.256 / 2016$, sugere-se a leitura de: NUNES, Dierle; FREITAS, Marina Carvalho. A necessidade de meios para superação dos precedentes. Revista de Processo: RePro, São Paulo, v. 43, n. 281, p. 433-489, jul.2018.

37 Art. 1.030. Recebida a petição do recurso pela secretaria do tribunal, o recorrido será intimado para apresentar contrarrazões no prazo de 15 (quinze) dias, findo o qual os autos serão conclusos ao presidente ou ao vice-presidente do tribunal recorrido, que deverá:

I - negar seguimento:

a) a recurso extraordinário que discuta questão constitucional à qual o Supremo Tribunal Federal não tenha reconhecido a existência de repercussão geral ou a recurso extraordinário interposto contra acórdão que esteja em conformidade com entendimento do Supremo Tribunal Federal exarado no regime de repercussão geral; b) a recurso extraordinário ou a recurso especial interposto contra acórdão que esteja em conformidade com entendimento do Supremo Tribunal Federal ou do Superior Tribunal de Justiça, respectivamente, exarado no regime de julgamento de recursos repetitivosII - encaminhar o processo ao órgão julgador para realização do juízo de retratação, se o acórdão recorrido divergir do entendimento do Supremo Tribunal Federal ou do Superior Tribunal de Justiça exarado, conforme o caso, nos regimes de repercussão geral ou de recursos repetitivos; $\quad$ (Incluído pela Lei n ${ }^{\circ}$ 13.256, de 2016)

III - sobrestar o recurso que versar sobre controvérsia de caráter repetitivo ainda não decidida pelo Supremo Tribunal Federal ou pelo Superior Tribunal de Justiça, conforme se trate de matéria constitucional ou infraconstitucional;

IV - selecionar o recurso como representativo de controvérsia constitucional ou infraconstitucional, nos termos do $\S 6^{\circ}$ do art. 1.036;

V - realizar o juízo de admissibilidade e, se positivo, remeter o feito ao Supremo Tribunal Federal ou ao Superior Tribunal de Justiça, desde que:

a) o recurso ainda não tenha sido submetido ao regime de repercussão geral ou de julgamento de recursos repetitivos;

b) o recurso tenha sido selecionado como representativo da controvérsia; ou

c) o tribunal recorrido tenha refutado o juízo de retratação.

$\S 1^{\circ} \mathrm{Da}$ decisão de inadmissibilidade proferida com fundamento no inciso $\mathrm{V}$ caberá agravo ao tribunal superior, nos termos do art. 1.042. 
presidente do tribunal de origem o dever de negar seguimento a recurso extraordinário e ao recurso especial quando, havendo precedente judicial obrigatório já formado no STF ou no STJ, o acórdão recorrido o contraria, ou, em outra situação, deixa de aplicá-lo.

Em que pese haver outros desdobramentos importantes a partir da redação do artigo 1.030 do CPC, nosso interesse nesta reflexão se volta unicamente para a mencionada hipótese em que o tribunal de origem deve negar seguimento aos recursos extremos, quando o acórdão do tribunal local está em conformidade com entendimento fixado em precedente obrigatório sobre o objeto da controvérsia (artigo (art. 1.030, I, "a", in fine, e art. 1.030, I, "b"). Isso porque essa realidade impede que as técnicas da distinção e da superação de precedentes sejam direcionadas à apreciação dos tribunais superiores, em clara afronta à própria dinâmica da estrutura dos precedentes e às competências constitucionalmente atribuídas a estas cortes. 38

Pela nova sistemática, após firmado o precedente obrigatório pelo STF ou pelo STJ (entendimento firmado pelo STF em repercussão geral ou pelo STF ou STJ em julgamento de recursos repetitivos), parece não ter sobrado alternativa recursal para que o jurisdicionado instigue o STF ou o STJ a fazer a distinção ou a superação do precedente que embasou a negativa de seguimento de seu recurso excepcional. Isso porque, de acordo com o $\S 2^{\circ}$ do artigo 1.030 do CPC, caso o recurso extraordinário ou especial tenha sido inadmitido pelo fato de o acórdão recorrido estar em conformidade com precedente obrigatório do STF ou do STJ, o recurso cabível não será o agravo a que se refere o artigo 1.042, destinado ao tribunal superior (art. 1.030, $\S 1^{\circ}$, do CPC), mas o agravo interno a que se refere o artigo 1.021 do CPC, destinado ao Pleno ou ao órgão especial do próprio tribunal de origem, a depender do que estiver previsto em seu regimento interno.

Isso implica que, caso o requerente queira demonstrar que o seu caso concreto contém peculiaridades que o diferenciam do precedente vinculante, ele deverá fazê-lo perante o tribunal local, por meio do agravo interno. O tribunal local, em caráter definitivo, é quem deverá se pronunciar sobre a adequação ou não do caso em análise ao precedente obrigatório paradigma, fazendo a necessária distinção, se for o caso. Tal significa que, nesse

$\S 2^{\circ}$ Da decisão proferida com fundamento nos incisos I e III caberá agravo interno, nos termos do art. 1.021. 38 MACÊDO, Lucas Buril. A análise dos recursos excepcionais pelos tribunais intermediários: o pernicioso art. 1.030 do CPC e sua inadequação técnica como fruto de uma compreensão equivocada do sistema de precedentes vinculantes. Revista de Processo: RePro, São Paulo, v. 41, n. 262, p. 187-221, dez. 2016. 
Rio de Janeiro. Ano 13. Volume 20. Número 3. Setembro a Dezembro de 2019

Periódico Quadrimestral da Pós-Graduação Stricto Sensu em Direito Processual da UERJ

Patrono: José Carlos Barbosa Moreira (in mem.). ISSN 1982-7636. pp. 546-574 www.redp.uerj.br

caso, como bem aponta Lucas Buril de Macêdo, o tribunal intermediário estará decidindo o mérito do recurso extremo, usurpando a missão constitucional atribuída ao tribunal superior.39 O STF e o STJ, portanto, permanecem alijados à técnica do distinguishing, que passou a constituir atribuição exclusiva dos diversos tribunais de segunda instância.

A situação se agrava quando se pensa na necessidade de se promover a superação dos precedentes oriundos do STF e do STJ (overrulling), porquanto esta somente pode ser feita pela própria Corte no âmbito da qual o precedente se formou. Diante do cenário que se apresenta a partir da nova redação do artigo 1.030 do CPC, em um primeiro momento, o que se vislumbra é que se tornou impossível ao jurisdicionado acessar as referidas cortes superiores, por meio do sistema recursal, se o objetivo for promover a superação de um precedente. Isso ficou claro, aliás, em diversos julgados do STJ, dentre estes o AREsp 1.170.332/SP40, objeto de comentário, em outra oportunidade, por Dierle Nunes e Marina Carvalho Freitas. 41

Nesse Agravo em Recurso Especial, observa-se que o Tribunal de Justiça do Estado de São Paulo negou seguimento ao recurso especial, com base no artigo 543-C, $\S 7^{\circ}$, I, do CPC de 1973, porque o acórdão recorrido encontrava-se em consonância com entendimento firmado em sede de recurso repetitivo (art. 543-C do CPC/1973), ou seja, um tipo de orientação jurisprudencial que, ao tempo da vigência do antigo Código, possuía caráter meramente persuasivo. O Relator, ao julgar o agravo, confirmou o entendimento que o STJ já vinha apresentando à época, no sentido de que somente o Tribunal de origem pode, com exclusividade e em caráter definitivo, proferir juízo de adequação do caso concreto ao precedente formado em repetitivo, não sendo viável, daí em diante, a apresentação de qualquer outro recurso dirigido ao STJ. Foi esse o entendimento transportado para a atual redação do artigo 1.030 do CPC de 2015 e que fechou as portas do STF e do STJ ao jurisdicionado para a tentativa de superação de entendimento firmado por essas cortes em recursos repetitivos ou em repercussão geral.

39 MACÊDO, Lucas Buril. A análise dos recursos excepcionais pelos tribunais intermediários: o pernicioso art. 1.030 do CPC e sua inadequação técnica como fruto de uma compreensão equivocada do sistema de precedentes vinculantes. Revista de Processo: RePro, São Paulo, v. 41, n. 262, p. 187-221, dez. 2016.

40 BRASIL, Superior Tribunal de Justiça, 4ªT., AREsp 1.170.332/SP, rela. Min. Luiz Felipe Salomão, j. 18/10/2017, DJe 7/11/2017.

41 NUNES, Dierle; FREITAS, Marina Carvalho. O STJ e a necessidade de meios para superação dos precedentes. Consultor Jurídico, 22 de novembro de 2017. Disponível em: < https://www.conjur.com.br/2017nov-22/opiniao-stj-meios-superacao-precedentes $>$ Acesso em 19 dez. 2018. 
Diante disso, a doutrina tem se esforçado na tentativa de elucidar quais os meios viáveis atualmente para ultrapassar essa barreira, haja vista que a vedação que se colocou de acesso aos tribunais superiores para a superação de seus padrões decisórios vinculantes não condiz com o atual modelo de precedentes instituído no CPC. Além disso, esse panorama destoa da premissa do artigo $1^{\circ}$ do $\mathrm{CPC}$, no sentido de que o processo civil se delineia a partir das normas fundamentais estabelecidas na Constituição, na medida em que, impõe absoluta restrição de acesso à jurisdição, contrariando o disposto no artigo $5^{\circ}, \mathrm{XXXV}$, da Carta Magna.

Dierle Nunes e Marina Freitas, em minucioso estudo acerca do tema, destrincham as soluções apontadas pela literatura jurídica para permitir o acesso às cortes superiores, em que pese a barreira imposta pelo art. 1.030 do CPC, que podem ser sintetizadas em duas possíveis hipóteses.42 A primeira se refere à aplicação de sugestões interpretativas para viabilizar a superação, a saber: opor embargos de declaração com fundamento nos artigos 1.022, parágrafo único, inciso II e artigo $489, \S 1^{\circ}$, incisos V e VI do CPC; interpretar o artigo 1.030 em conformidade com a Constituição, devendo o tribunal local permitir a subida do recurso extraordinário ou especial ao STF ou ao STJ, mesmo quando houver contrariedade a precedente obrigatório dessas cortes, quando o recorrente alegar a possibilidade de superação; ou realizar a alteração legislativa do artigo 1.030 do CPC para adequá-lo ao sistema de precedentes.

Uma segunda possibilidade apresentada, segundo o referido estudo, consiste em aplicar os seguintes mecanismos dogmáticos, apontados com algumas divergências entre os diversos doutrinadores que os defendem: a) ajuizar ação rescisória contra a decisão transitada em julgado que nega provimento ao agravo interno e impede a subida do recurso especial ou extraordinário à respectiva Corte Superior, com fulcro no artigo 966, $\S \S 5^{\circ}$ e $6^{\circ}$, do CPC; c) aplicar a técnica do julgamento-alerta, por meio da qual o tribunal superior indica aos tribunais locais que determinado precedente perdeu sua força e está em vias de ser superado; d) interpor o agravo previsto no artigo 1.042 do CPC contra a decisão que negou provimento ao agravo interno interposto anteriormente com base no artigo 1.021 do CPC; e) ajuizar reclamação contra a decisão do agravo interno que mantém a inadmissibilidade do

42 NUNES, Dierle; FREITAS, Marina Carvalho. A necessidade de meios para superação dos precedentes. Revista de Processo: RePro, São Paulo, v. 43, n. 281, p. 433-489, jul.2018. 
recurso especial ou extraordinário, sob o fundamento de que houve aplicação indevida da tese jurídica objeto do precedente obrigatório ou sua não aplicação aos casos correspondentes, com fulcro no artigo $988, \S 4^{\circ}$, do CPC; e f) interpor novo recurso especial ou extraordinário, alternativa defendida por Dierle Nunes e Marina Freitas.43

Este ensaio não tem como objetivo dissertar sobre o procedimento e a (in)eficácia de cada um dos mecanismos apontados pela doutrina, o que já fora realizado com propriedade por Dierle Nunes e Marina Freitas, nem mesmo defender a prevalência de uma ou outra técnica para viabilizar a superação de precedentes obrigatórios pelo STF ou pelo STJ. Acredita-se que, no atual cenário de aplicação do artigo 1.030 do CPC, todas as medidas suscitadas são bem-vindas para permitir o acesso do jurisdicionado às referidas cortes, de forma a impedir que a dinâmica do sistema de precedentes sucumba ao império da jurisprudência defensiva daqueles tribunais. O que se deseja nesta sede, uma vez mais, é demonstrar a importância adquirida pela reclamação no curso de sua trajetória histórica, apontando a possibilidade de sua utilização como técnica de overruling na atualidade.

Já tivemos oportunidade de nos referir, em linhas anteriores, que a possibilidade de haver distinção e superação do precedente obrigatório em sede de reclamação foi reconhecida pelo STF a partir do julgamento da Rcl 4.374/PE. Abordou-se também que Gustavo Azevedo considera essa possibilidade uma das consequências do ajuizamento da reclamação, embora não possa, segundo esse autor, constar do pedido da ação reclamatória. ${ }^{44}$ Dierle Nunes e Marina Freitas também se posicionam contrariamente ao ajuizamento de reclamação com vistas à superação de precedentes, por entenderem que essa intenção contraria o escopo constitucionalmente atribuído à reclamação, a qual se presta exatamente a garantir a autoridade das decisões dos tribunais e não a refutá-la. ${ }^{45}$ Esse mesmo

43 NUNES, Dierle; FREITAS, Marina Carvalho. A necessidade de meios para superação dos precedentes. Revista de Processo: RePro, São Paulo, v. 43, n. 281, p. 433-489, jul.2018. Esse é o entendimento compartilhado também por Alexandre Freitas Câmara: CÂMARA, Alexandre Freitas. Novo CPC reformado permite superação de decisões vinculantes. Consultor Jurídico, 12 de fevereiro de 2016. Disponível em < https://www.conjur.com.br/2016-fev-12/alexandre-camara-cpc-permite-superacao-decisoes-vinculantes> Acesso em 17-12-2018.

44 AZEVEDO, Gustavo. Reclamação constitucional no direito processual civil. Rio de Janeiro: Forense, 2018.p 202.

45 NUNES, Dierle; FREITAS, Marina Carvalho. A necessidade de meios para superação dos precedentes. Revista de Processo: RePro, São Paulo, v. 43, n. 281, p. 433-489, jul.2018. 
entendimento é compartilhado por Rodrigo Becker e Victor Trigueiro em artigo sobre o assunto. $^{46}$

Em sentido contrário, com Fredie Didier Jr. e Leonardo Carneiro da Cunha, defendese aqui que a reclamação constitui um valioso mecanismo disponível ao jurisdicionado para acessar as cortes superiores quando o que se deseja é a superação de seus precedentes. Não se está negando, com isso, que a essência do instituto é preservar a autoridade das decisões desses tribunais. Todavia, a partir da sistematização de padrões decisórios instituída pelos artigos 926 e 927 do CPC, consolidando uma teoria de precedentes vinculantes no Brasil, torna-se natural que a autoridade das decisões possa ser questionada pelo jurisdicionado em algum momento, não havendo óbice para que isso seja feito pela mesma via através da qual se intenta preservá-la.

Afinal, se, conforme pronunciado pelo STF na Rcl 4.374/PE, a reclamação confere aos tribunais oportunidade de redefinir o alcance e o conteúdo de suas decisões, no "balançar de olhos" entre o caso concreto e o precedente paradigma, não há razões, então, para que o jurisdicionado seja impedido de utilizar dessa mesma ferramenta de acesso para provocar a superação de entendimento pelos tribunais superiores. Essa compreensão parece ter ficado clara no julgamento da Rcl 25.078/SP ${ }^{47}$, em que o Relator, Ministro Dias Toffoli, assim se pronunciou, com destaques presentes no original:

Por atribuição constitucional, presta-se a reclamação para preservar a competência do STF e garantir a autoridade de suas decisões (art. 102, inciso I, alínea L, CF/88), bem como para resguardar a correta aplicação das súmulas vinculantes (art. 103-A, § $3^{\circ}, \mathrm{CF} / 88$ ). A reclamatória, neste aspecto, exsurge como instrumento de promoção do diálogo, nesta Suprema Corte, entre o caso concreto e os precedentes obrigatórios, cuja admissibilidade está condicionada à efetiva demonstração de desrespeito à autoridade da decisão do STF, porquanto configurada erronia na aplicação do entendimento vinculante a evidenciar teratologia da decisão reclamada; usurpação da competência do STF, pois existente, i) no caso concreto, peculiaridades que impossibilitam a aplicação adequada da norma de interpretação extraída do precedente (distinguishing) a demandar pronunciamento desta Suprema Corte acerca da matéria

46 Com opinião contrária, cite-se BECKER, Rodrigo; TRIGUEIRO, Victor. Reclamação Constitucional para superação de precedentes. Jota Info, 8/12/2016. Disponível em < https://www.jota.info/opiniao-eanalise/colunas/coluna-cpc-nos-tribunais/reclamacao-constitucional-para-superacao-de-precedentes-

08122016> Acesso em 17-12-2018.

47 BRASIL, Supremo Tribunal Federal, $2^{a}$ T., Rcl 25078 AgR/SP, Rel. Min. Dias Toffoli, j. 13/12/2016. DJE $n^{\circ} 34$ de 20/02/2017. 
constitucional no caso concreto, acaso verificada repercussão geral, ou, ii) em hipóteses excepcionais, a necessidade de revisitação dos fundamentos do precedente, tendo em vista a alteração do ordenamento jurídico vigente ao tempo do julgamento ou das circunstâncias fáticas históricas que impactaram a interpretação da norma, com possibilidade de sua superação (overruling).

Respeitada a necessidade de racionalização e estabilização da prestação jurisdicional - com vistas à promoção do princípio da segurança jurídica -, porém com o cuidado de não gerar a petrificação da jurisprudência desta Corte, é lídimo que se outorgue, em matéria constitucional, a esta Suprema Corte a última palavra também sobre a aplicação de seus precedentes, oportunizando-se sua preservação ou evolução, quando for o caso, ao mesmo tempo em que se respeita a competência recursal ordinária para fins de subsunção dos fatos e das provas do caso concreto à tese constitucional firmada pelo STF em repercussão geral ${ }^{48}$.

Na perspectiva desse raciocínio, quando o tribunal local nega seguimento a recurso extraordinário interposto contra acórdão em conformidade com entendimento do STF exarado no regime de repercussão geral ou a recurso extraordinário ou especial interposto contra acórdão em conformidade com entendimento do STF ou do STJ, respectivamente, proferido conforme a sistemática de julgamento de recursos repetitivos (art. 1.030, alíneas "a" e "b", do CPC), tem-se a seguinte situação: o recorrente deve necessariamente interpor agravo interno a que se refere o artigo 1.021 do CPC (cf. determina o art. 1.030, § $2^{\circ}$, do CPC), demonstrando ao tribunal local as razões pelas quais o precedente não se aplica ao caso em análise. Desprovido o agravo interno, caberá reclamação nos termos do artigo 988, $\S 5^{\circ}$, II, do CPC.

Isso porque a redação do artigo $988, \S 5^{\circ}$, II, do CPC, a nosso ver, amplia o conteúdo de sentido do art. 988, $\S 4^{\circ}$, caso haja o implemento da condição imposta, qual seja, o esgotamento das vias ordinárias. Isso leva ao entendimento de que, se o tribunal local deixou de aplicar ou aplicou indevidamente a tese jurídica proferida em acórdão de recurso extraordinário com repercussão geral reconhecida ou de acórdão proferido em julgamento de recursos extraordinário ou especial repetitivos (situação não contida nos incisos III e IV do art. 988) e houve o esgotamento das instâncias ordinárias, caberá reclamação. Essa parece ser a melhor interpretação que se deve fazer do conjunto do artigo 988 do CPC, sobretudo considerando o fato de que a lei não costuma trazer palavras inúteis.

48 Decisão monocrática disponível $\quad$ em


A reclamação terá, na situação acima descrita, seu pressuposto de admissibilidade preenchido, qual seja, o esgotamento das vias ordinárias, porque após a interposição de agravo interno não há outro recurso a ser interposto. No mérito, deverá o reclamante fundamentar o pedido: a) no desrespeito à autoridade da decisão do tribunal superior, se foi o caso de erro do tribunal local na aplicação da tese jurídica fixada em precedente obrigatório ou se deixou de aplicá-la; ou b) na usurpação de competência do tribunal superior em questão, hipótese em que o requerente deverá apresentar os argumentos que deverão levar a corte superior a realizar o distinguishing ou o overruling.

$\mathrm{O}$ mesmo entendimento restou consignado recentemente no julgamento da Rcl 28.605/DF49, de relatoria também do Ministro Dias Toffoli. Denota-se do caso concreto que a reclamação foi ajuizada contra decisão do Tribunal Superior do Trabalho (TST), que negou seguimento a recurso extraordinário com fundamento na aplicação equivocada de precedente obrigatório do STF (repercussão geral conferida no julgamento dos ARE n ${ }^{\circ}$ s 748.371/MTRG e 742.083/DF-RG). Neste caso, verifica-se que a aplicação indevida da tese jurídica pelo tribunal de origem não se deu em relação aos precedentes a que se referem os incisos III e IV do artigo 988, em conformidade com o que determina o art. $988, \S 4^{\circ}$, do CPC, mas, ainda assim, a reclamação foi aceita pelo STF, porque houve esgotamento das instâncias ordinárias, enquadrando-se na situação descrita no art. 988, § 5 , II, do CPC.

Uma ressalva merece ser feita caso a hipótese seja de superação do precedente vinculante a partir do julgamento de reclamação. Não se pode permitir que um precedente forte, formado a partir do julgamento do órgão colegiado competente do tribunal superior, que observou o contraditório dinâmico ao longo de todo o procedimento, seja desconstituído de forma simplista, a partir de um órgão fracionário do respectivo tribunal, de forma autoritária. É preciso que o mesmo procedimento de formação do precedente seja aplicado em sua alteração, respeitando-se, ainda, a competência para realizá-la.

Cite-se, a título de exemplo, hipótese em que o tribunal superior opta por revogar uma decisão proferida em controle concentrado de constitucionalidade, com eficácia erga omnes, tal como ocorreu no julgamento da Rcl 4.374/PE no STF, a que se fez referência no terceiro tópico deste ensaio. Deve-se observar, nesse tipo de situação, a necessidade de

49 BRASIL, Supremo Tribunal Federal, 2a T., Rcl 28605 AgR/DF, Rel. Min. Dias Toffoli, j. 29/6/2018. DJE $\mathrm{n}^{\circ} 174$ de $24 / 08 / 2018$. 
manifestação da Advocacia-Geral da União, de intimação da Procuradoria-Geral da República para emissão de parecer e de abertura à participação de amici curiae, nos mesmos moldes em que se deu a formação do precedente a ser desconstituído.

Em tais condições, endossando o posicionamento de Fábio Lima Quintas e Alcebíades Galvão César Filho50, entende-se que, recebida a reclamação pelo tribunal superior respectivo e tendo a turma julgadora se convencido da necessidade de revisão do precedente, deve submeter o feito ao julgamento do Plenário, conforme o procedimento previsto no respectivo regimento interno. O Plenário, de seu turno, deve providenciar para que se observe o efetivo contraditório, em respeito ao devido processo legal.

Advoga-se, portanto, que a reclamação se transformou ao longo dos tempos em importante espaço procedimental para promoção do diálogo dos tribunais com os seus próprios precedentes, bem como entre os jurisdicionados e os tribunais, com vistas a manter o direito jurisprudencial em constante evolução.

\section{CONCLUSÃO}

A reclamação constitucional foi adquirindo, ao longo de sua evolução histórica, importância inimaginável ao tempo de sua origem, na jurisprudência do STF. É inegável o quanto o instituto se aprimorou, passando da fase jurisprudencial à fase constitucionalizada, tendo seus contornos recentemente ampliados na fase processual codificada.

Pode-se dizer que se trata hoje de um dos mais relevantes meios de controle da autoridade das decisões dos tribunais, sobretudo na atual sistemática de precedentes vinculantes instituída no CPC de 2015. Por outro lado, a reclamação se tornou o locus em que o próprio tribunal rediscute a aplicação de sua decisão vinculante, perquirindo sobre a sua sustentabilidade.

Conforme ressaltado pelo próprio STF, é no momento em que a Corte Superior aprecia uma reclamação, que surge a oportunidade de dialogar com seus próprios precedentes, de rever o conteúdo e o alcance de suas decisões, vindo a reinterpretá-las ou até

50 QUINTAS, Fábio Lima; CÉSAR FILHO, Alcebíades Galvão. Serve a reclamação constitucional para modificar precedentes? Consultor Jurídico, 10 de fevereiro de 2018. Disponível em < https://www.conjur.com.br/2018-fev-10/observatorio-constitucional-serve-reclamacao-constitucionalmodificar-precedentes> Acesso em 21 dez. 2018. 
mesmo a superá-las caso não mais se mostrem pertinentes no novo cenário social ou perante a ordem jurídica vigente.

É consenso entre os juristas que os padrões decisórios não são imutáveis, o que iria de encontro à doutrina de precedentes e à própria Constituição. Logo, os tribunais superiores não podem petrificar sua jurisprudência, vindo a alterá-la somente quando lhes convier. Há de haver meios para que os jurisdicionados, de forma comparticipada, levem suas ponderações até essas cortes, demonstrando que seus entendimentos precisam ser revistos.

Por essa razão é que não se pode considerar absurdo o manejo da reclamação para provocar o STF e o STJ à superação de seus julgados, já que o artigo 1.030 do CPC estabeleceu uma indesejada barreira ao acesso dos sujeitos processuais a essas cortes. A reclamação se apresenta, nesse caso, como uma via de mão dupla entre os jurisdicionados e as cortes para impulsionar o constante diálogo entre as situações jurídicas concretas e os motivos determinantes dos precedentes vinculantes.

\section{REFERÊNCIAS}

AZEVEDO, Gustavo. Reclamação constitucional no direito processual civil. Rio de Janeiro: Forense, 2018.

BECKER, Rodrigo; TRIGUEIRO, Victor. Reclamação Constitucional para superação de precedentes. Jota Info, 8/12/2016. Disponível em < https://www.jota.info/opiniao-eanalise/colunas/coluna-cpc-nos-tribunais/reclamacao-constitucional-para-superacaode-precedentes-08122016> Acesso em 17-12-2018.

BRASIL. Constituição (1988). Constituição da República Federativa do Brasil. Brasília: Senado, 1988.

BRASIL. Lei 5.869, de 11 de janeiro de 1973. Código de Processo Civil. Diário Oficial da União, Brasília, DF, 17 jan. 1973. Disponível em: http://www.planalto.gov.br/ccivil_03/LEIS/L5869.htm>Acesso em 19 dez. 2018.

BRASIL. Lei n. 13.105, de 16 de março de 2015. Código de Processo Civil. Diário Oficial da União, Brasília, DF, 17 mar. 2015. Disponível em: <http://www.planalto.gov.br/ccivil_03/_Ato2015-2018/2015/Lei/L13105.htm> Acesso em: 19 dez. 2018. 
BRASIL, Supremo Tribunal Federal, Plenário, Rcl 4374/PE, Rel. Min. Gilmar Mendes, j. 18//2013, Dje 4/9/2013.

BRASIL, Supremo Tribunal Federal, 2a T., Rcl 25078 AgR/SP, Rel. Min. Dias Toffoli, j. 13/12/2016. DJE n ${ }^{\circ} 34$ de 20/02/2017.

BRASIL, Superior Tribunal de Justiça, $4^{a}$ T., AREsp 1.170.332/SP, Rel. Min. Luiz Felipe Salomão, j. 18/10/2017, DJe 7/11/2017.

BRASIL, Supremo Tribunal Federal, 2a T., Rcl 28605 AgR/DF, Rel. Min. Dias Toffoli, j. 29/6/2018. DJE n 174 de 24/08/2018.

CÂMARA, Alexandre Freitas. Novo CPC reformado permite superação de decisões vinculantes. Consultor Jurídico, 12 de fevereiro de 2016. Disponível em < https://www.conjur.com.br/2016-fev-12/alexandre-camara-cpc-permite-superacaodecisoes-vinculantes> Acesso em 17-12-2018.

DANTAS, Marcelo Ribeiro Navarro. A reclamação constitucional no Direito comparado. In: COSTA, Eduardo José da Fonseca; NOGUEIRA, Pedro Henrique Pedrosa (Org.). Reclamação constitucional. Salvador: Juspodium, 2013.

DIDIER JR., Fredie; CUNHA, Leonardo Carneiro. Curso de direito processual civil: meios de impugnação às decisões judiciais e processo nos tribunais. 13. Ed. Salvador: Juspodium, 2016. V.3.

MENDONÇA NETO, Jouberto Uchôa de. A reclamação constitucional no novo código de processo civil. p. 4-6. Disponível em > http://www.esasergipe.org.br/wpcontent/uploads/2016/11/A-reclama\%C3\%A7\%C3\%A3o-constitucional-no-NovoC\%C3\%B3digo-de-Processo-Civil.pdf> Acesso em 11 dez. 2018.

NUNES, Dierle José Coelho. Processo jurisdicional democrático: uma análise crítica das reformas processuais. Curitiba: Juruá, 2012.

NUNES, Dierle; FREITAS, Marina Carvalho. O STJ e a necessidade de meios para superação dos precedentes. Consultor Jurídico, 22 de novembro de 2017. Disponível em: < https://www.conjur.com.br/2017-nov-22/opiniao-stj-meios-superacaoprecedentes> Acesso em 19 dez. 2018.

NUNES, Dierle; FREITAS, Marina Carvalho. A necessidade de meios para superação dos precedentes. Revista de Processo: RePro, São Paulo, v. 43, n. 281, p. 433-489, jul.2018. 
Rio de Janeiro. Ano 13. Volume 20. Número 3. Setembro a Dezembro de 2019

Periódico Quadrimestral da Pós-Graduação Stricto Sensu em Direito Processual da UERJ

Patrono: José Carlos Barbosa Moreira (in mem.). ISSN 1982-7636. pp. 546-574

www.redp.uerj.br

QUINTAS, Fábio Lima; CÉSAR FILHO, Alcebíades Galvão. Serve a reclamação constitucional para modificar precedentes? Consultor Jurídico, 10 de fevereiro de 2018. Disponível em < https://www.conjur.com.br/2018-fev-10/observatorio-

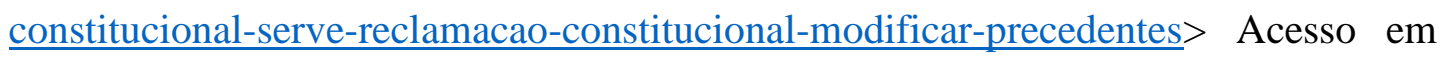
21 dez. 2018.

SARMENTO, Daniel. O neoconstitucionalismo no Brasil: riscos e possibilidades. Rio de Janeiro, 2009. Texto disponível em <http://www.dsarmento.adv.br/content/3publicacoes/16-o-neoconstitucionalismo-no-brasil-riscos-e-possibilidades/oneoconstitucionalismo-no-brasil.riscos-e-possibilidades-daniel-sarmento.pdf $>$ Acesso em 13. Dez. 2018.

THEODORO JÚNIOR, Humberto et al. Novo CPC: fundamentos e sistematização. 3.ed. Rio de Janeiro: Forense, 2016.

VIANA, Aurélio; NUNES, Dierle. Precedentes: a mutação no ônus argumentativo. Rio de Janeiro: Forense, 2018. 